\title{
SUMBER HISTORIS PENDIDIKAN PANCASILA
}

\author{
Natasya Wendika Putri \\ wendikanatasya@gmail.com \\ 20220068 \\ AKBP-STIE"KBP"PADANG
}

\section{A. Pendahuluan}

Indonesia merupakan Negara yang memiliki bentuk Negara kepulauan dan bentuk pemerintahan republic sehingga disebut dengan Negara Kesatuan Republik Indonesia (NKRI), dan masyarakatnya tidak asing lagi dengan pancasila. Dalam kehidupan berbangsa dan bernegara, masyarakat Indonesia mengenal pancasila sebagai dasar Negara, pedoman, dan pandangan hidup,yang nilainya diangkat dari kehidupan masyarakat sendiri. Pancasila merupakan dasar Negara, dan juga menjadi falsafah hidup bangsa Indonesia sejak dahulu. Pancasila juga diperuntukkan kepada Negara,masyarakat, dan pribadi bangsa Indonesia. Silasila pancasila itu tidak terlepas satu sama lain melainkan satu kesatuan yang bulat, baik dalam fungsi dan kedudukannya sebagai dasar Negara maupun sebagai falsafah hidup bangsa.Pengertian dari kata "kesatuan bulat" dari pancasila ini ialah berarti bahwa sila yang satu meliputi dan menjiwai sila-sila yang lain.Lantas perumusan pancasila juga dapat dijadikan sebagai pandangan hidup bangsa yang selalu berkaitan dengan kehidupan berbangsa dan bernegara. Seperti yang telah diketahui bahwa pancasila itu juga merupakan dasar Negara Indonesia, yang berarti dasar dari hukum tertinggi di Indonesia atau sumber dari segala sumber hukum di Indonesia. Hal ini terdapat pada Pembukaan Undang-Undang Dasar 1945, yang merupakan Naskah Proklamasi Indonesia. Pancasila juga merupakan ideology terbuka, yaitu bersifat khas dan orisinil. Kelima sila dalam pancasila ini memang bersifat universal sehingga dapat ditemukan dalam gagasan berbagai masyarakat lain. Letak kekhasan 
dan orisinilitasnya yaitu sebagai falsafah dan ideology Negara. Pancasila juga berperan dalam sejarah ketatanegaraan Republik Indonesia yaitu yang berpusat pada Undang-Undang Dasar 1945 yang benar. benar harus dijiwai oleh seluruh masyarakat Indonesia. Negara yang berpaham kedaulatan rakyat, yaitu Negara tidak bisa memaksakan

kehendaknya kepada rakyat karena rakyat adalah sumber dari kekuasaan Negara. Sedangkan arah perumusan norma-norma hukum harus memberikan jaminan kemudahan dan kesempatan yang seluas-luasnya bagi rakyat untuk menunjukkan bahwa rakyatlah yang berdaulat. Untuk itu sebagai warga Negara yang baik dan bertanggung jawab seharusnya masyarakat mengikuti dan mematuhi pancasila, karena seperti pemaparan di atas telah disebutkan bahwa pancasila adalah sumber dari segala sumber hukum atau dasar Negara yang harus dipatuhi. Karena dalam sila-sila pancasila tidak memihak kepada satu orang saja melainkan keseluruh warga Negara Indonesia. Adapun tujuan dalam pembuatan makalah ini ialah Untuk mengetahui sejarah perumusan pancasila.Selain itu Untuk mengetahui makna dari pancasila sebagai dasar Negara dan peranan pancasila dalam ketatanegaraan Republik Indonesia,dan Untuk menambah wawasan siswa tentang sejarah pancasila.

\section{B. Pembahasan}

Sumber Historis Pendidikan Pancasila Presiden Soekarno pernah mengatakan, "Jangan sekalikali meninggalkan sejarah.” Pernyataan tersebut dapat dimaknai bahwa sejarah mempunyai fungsi penting dalam membangun kehidupan bangsa dengan lebih bijaksana di masa depan. Hal tersebut sejalan dengan ungkapan seorang filsuf Yunani yang bernama Cicero (106-43SM) yang mengungkapkan, "Historia Vitae. Magistra", yang bermakna, "Sejarah memberikan kearifan". Pengertian lain dari istilah tersebut yang sudah menjadi pendapat umum (commonsense) adalah "Sejarah merupakan guru kehidupan". Implikasinya, pengayaan materi perkuliahan Pancasila melalui pendekatan historis adalah amat penting dan tidak boleh 
dianggap remeh guna mewujudkan kejayaan bangsa di kemudian hari. Melalui pendekatan ini, mahasiswa diharapkan dapat mengambil pelajaran atau hikmah dari berbagai peristiwa sejarah, baik sejarah nasional maupun sejarah bangsa-bangsa lain. Dengan pendekatan historis, Anda diharapkan akan memperoleh inspirasi untuk berpartisipasi dalam pembangunan bangsa sesuai dengan program studi masing-masing. Selain itu, Anda juga dapat berperan serta secara aktif dan arif dalam berbagai kehidupan berbangsa dan bernegara, serta dapat berusaha menghindari perilaku yang bernuansa mengulangi kembali kesalahan sejarah. Dalam peristiwa sejarah nasional, banyak hikmah yang dapat dipetik, misalnya mengapa bangsa Indonesia sebelum masa pergerakan nasional selalu mengalami kekalahan dari penjajah? Jawabannya antara lain karena perjuangan pada masa itu masih bersifat kedaerahan, kurang adanya persatuan, mudah dipecah belah, dan kalah dalam penguasaan IPTEKS termasuk dalam bidang persenjataan. Hal ini berarti bahwa apabila integrasi Nilai-nilai Pancasila sudah ada dalam adat istiadat, kebudayaan, dan agama yang berkembang dalam kehidupan bangsa Indonesia sejak zaman kerajaan dahulu. Misalnya, sila Ketuhanan sudah ada pada zaman dahulu, meskipun dalam praktik pemujaan yang beranekaragam, tetapi pengakuan tentang adanya Tuhan sudah diakui. Dalam Encyclopedia of Philosophy disebutkan beberapa unsur yang ada dalam agama, seperti kepercayaan kepada kekuatan supranatural, perbedaan antara yang sakral dan yang profan, tindakan ritual pada objek sakral, sembahyang atau doa sebagai bentuk komunikasi kepada Tuhan, takjub sebagai perasaan khas keagamaan, tuntunan moral diyakini dari Tuhan, konsep hidup di dunia dihubungkan dengan Tuhan, kelompok sosial seagama dan seiman. Pancasila pada hakikatnya merupakan Philosofische Grondslag dan Weltanschauung. Pancasila dikatakan sebagai dasar filsafat negara (Philosofische Grondslag) karena mengandung unsurunsur sebagai berikut: alasan filosofis berdirinya suatu negara; setiap produk hukum di Indonesia harus berdasarkan nilai Pancasila. Pancasila sebagai pandangan hidup bangsa 
(Weltanschauung) mengandung unsur-unsur sebagai berikut: nilai-nilai agama, budaya, dan adat istiadat. Hasil Survei yang dilakukan KOMPAS yang dirilis pada 1 Juni 2008 menunjukkan bahwa pengetahuan masyarakat tentang Pancasila merosot secara tajam, yaitu 48,4\% responden berusia 17 sampai 29 tahun tidak mampu menyebutkan silai-sila Pancasila secara benar dan lengkap. 42,7\% salah menyebut sila-sila Pancasila, lebih parah lagi, 60\% responden berusia 46 tahun ke atas salah menyebutkan sila-sila Pancasila. Fenomena tersebut sangat memprihatinkan karena menunjukkan bahwa pengetahuan tentang Pancasila yang ada dalam masyarakat tidak sebanding dengan semangat penerimaan masyarakat terhadap Pancasila (Ali, 2009: 2). Selain data tersebut, pentingnya Pancasila dalam sejarah bangsa Indonesia dikarenakan hal-hal berikut: pengidentikan Pancasila dengan ideologi lain, penyalahgunaan Pancasila sebagai alat justifikasi kekuasaan rezim tertentu, melemahnya pemahaman dan pelaksanaan nilai Pancasila dalam kehidupan berbangsa dan bernegara. Pengertian Pancasila dalam sejarah bangsa Indonesia menunjukkan hal-hal sebagai berikut:

1. Pancasila merupakan produk otentik pendiri negara Indonesia (The Founding fathers).

2. Nilai-nilai Pancasila bersumber dan digali dari nilai agama, kebudayaan, dan adat istiadat.

3. Pancasila merupakan pandangan hidup bangsa dan dasar filsafat kenegaraan.Pentingnya Pancasila dalam sejarah bangsa Indonesia menunjukkan hal-hal berikut:

1. Betapapun lemahnya pemerintahan suatu rezim, tetapi Pancasila tetap bertahan dalam kehidupan berbangsa dan bernegara.

2. Betapapun ada upaya untuk mengganti Pancasila sebagai ideologi bangsa, tetapi terbukti Pancasila merupakan pilihan yang terbaik bagi bangsa Indonesia.

3. Pancasila merupakan pilihan terbaik bagi bangsa Indonesia karena bersumber dan digali dari nilai-nilai agama, kebudayaan, dan adat istiadat yang hidup dan berkembang di bumi Indonesia. 
4. Kemukakan argumen Anda tentang Pancasila sebagai pilihan terbaik bangsa Indonesia. Pancasila sebagai dasar negara sering juga disebut sebagai Philosophische Grondslag dari negara, ideologi negara, staatsidee. Dalam hal tersebut,Pancasila digunakan sebagai dasar mengatur pemerintah negara. Atau dengan kata lain, Pancasila digunakan sebagai dasar untuk mengatur penyelenggaraan negara (Darmodiharjo, 1991: 19).Dengan demikian, jelas kedudukan Pancasila itu sebagai dasar negara, Pancasila sebagai dasar negara dibentuk setelah menyerap berbagai pandangan yang berkembang secara demokratis dari para anggota BPUPKI dan PPKI sebagai representasi bangsa Indonesia (Pimpinan MPR dan Tim Kerja Sosialisasi MPR periode 2009--2014, 2013: 94). Pancasila dijadikan sebagai. Dasar negara,yaitu sewaktu ditetapkannya Pembukaan Undang-Undang Dasar Negara Kesatuan Republik Indonesia tahun 1945 pada 8 Agustus 1945. Pada mulanya, pembukaan direncanakan pada tanggal 22 Juni 1945, yang terkenal dengan Jakarta-charter (Piagam Jakarta), tetapi Pancasila telah lebih dahulu diusulkan sebagai dasar filsafat negara Indonesia merdeka yang akan didirikan, yaitu pada 1 Juni 1945, dalam rapat Badan Penyelidik Usaha-usaha Persiapan Kemerdekaan Indonesia (Notonagoro, 1994: 24). Terkait dengan hal tersebut, Mahfud MD (2009:14) menyatakan bahwa berdasarkan penjelajahan historis diketahui bahwa Pancasila yang berlaku sekarang merupakan hasil karya bersama dari berbagai aliran politik yang ada di BPUPKI, yang kemudian disempurnakan dan disahkan oleh PPKI pada saat negara didirikan. Lebih lanjut, Mahfud MD menyatakan bahwa ia bukan hasil karya Moh. Yamin ataupun Soekarno saja, melainkan hasil karya bersama sehingga tampil dalam bentuk, isi, dan filosofinya yang utuh seperti sekarang.

\section{Pembahasan}

Pancasila merupakan dasar Negara, dan juga menjadi falsafah hidup bangsa Indonesia sejak dahulu. Pancasila juga diperuntukkan kepada Negara, masyarakat, dan pribadi bangsa Indonesia Pancasila berasal dari kata panca yang berarti lima dan sila yang berarti dasar, sendi 
,asas, ata peraturan tingkah laku yang penting dan baik .dengan demikian pancasila merupakan lima dasar yang berisi pedoman atau aturan tentang tingkah laku yang penting dan baik.Pancasila dapat kita artikan sebagai lma dasar yang dijadikan dasar negara serta pandangan hidup bangsa.Suatu bangsa tidak akan dapat berdiri dengan kokoh tampa dasar negara yang kuat dan tidak dapat mengetahui dengan jelas kemana arah tujuan yang akan dicapai tampa pandangan hidup. Dengan adanya dasar negara, suatu bangsa tidak akan terombang ambing dalam menghadapi permasalahan baik yang dari dalam maupun dari luar. Sila-sila pancasila itu tidak terlepas satu sama lain melainkan satu kesatuan yang bulat, baik dalam fungsi dan kedudukannya sebagai dasar Negara maupun sebagai falsafah hidup bangsa.Pengertian dari kata "kesatuan bulat" dari pancasila ini ialah berarti bahwa sila yang satu meliputi dan menjiwai sila-sila yang lain.Sila-sila pancasila itu tidak statis, akan tetapi dinamis, dengan gerakan-gerakannya yang positif dan serasi, karena ketatanegaraan akan selalu berkaitan dengan tata negara. Karena tata begara merupakan pengatur kehidupan bernegara yang mennyangkut sifat, bentuk, tugas negara,dan pemerintahannya. Karena banyak peristiwa-peristiwa penting yang terjadi yaitu seperti krisis-krisis yang menimpa bangsa bangsa dan negara, sebagai reaksi terhadap gejolak kehidupan bangsa tampak menonjol satu atau beberapa sila saja. Dari kalimat diatas telah diketahui bahwa pancasila sangat berperan untuk keutuhan negara. Dengan kelima sila tersebut kehidupan masyarakat akan lebih terarah.

\section{DAFTAR PUSTAKA}

Darmini Roza dan Laurensius Arliman S Peran Pemerintah Daerah Di Dalam Melindungi Hak Anak Di Indonesia, Masalah-Masalah Hukum, Volume 47, Nomor 1, 2018.

Laurensius Arliman S, Komnas HAM dan Perlindungan Anak Pelaku Tindak Pidana, Deepublish, Yogyakarta, 2015.

Laurensius Arliman S, Penguatan Perlindungan Anak Dari Tindakan Human Trafficking Di Daerah Perbatasan Indonesia, Jurnal Selat, Volume 4, Nomor 1, 2016. 
Laurensius Arliman S, Problematika Dan Solusi Pemenuhan Perlindungan Hak Anak Sebagai Tersangka Tindak Pidana Di Satlantas Polresta Pariaman, Justicia Islamica, Volume 13, Nomor 2, 2016.

Laurensius Arliman S, Pelaksanaan Perlindungan Anak Yang Tereksploitasi Secara Ekonomi Oleh Pemerintah Kota Padang, Veritas et Justitia, Volume 2, Nomor 1, 2016.

Laurensius Arliman S, Kedudukan Ketetapan MPR Dalam Hierarki Peraturan Perundang-Undangan Di Indonesia, Lex Jurnalica, Volume 13, Nomor 3, 2016.

Laurensius Arliman S, Komnas Perempuan Sebagai State Auxialiary Bodies Dalam Penegakan Ham Perempuan Indonesia, Justicia Islamica, Volume 14, Nomor 2, 2017.

Laurensius Arliman S, Peranan Pers Untuk Mewujudkan Perlindungan Anak Berkelanjutan Di Indonesia, Jurnal Ilmu Hukum Tambun Bungai, Volume 2, Nomor 2, 2017.

Laurensius Arliman S, Mewujudkan Penegakan Hukum Yang Baik Untuk Mewujudkan Indonesia Sebagai Negara Hukum, Jurnal Hukum Doctrinal, Volume 2, Nomor 2, 2017.

Laurensius Arliman S, Participation Non-Governmental Organization In Protecting Child Rights In The Area Of Social Conflict, The 1st Ushuluddin and Islamic Thought International Conference (Usicon), Volume 1, 2017.

Laurensius Arliman S, Partisipasi Masyarakat Dalam Pembentukan Perundang-Undangan Untuk Mewujudkan Negara Kesejahteraan Indonesia, Jurnal Politik Pemerintahan Dharma Praja, Volume 10, Nomor 1, 2017, https://doi.org/10.33701/jppdp.v10i1.379.

Laurensius Arliman S, Peran Komisi Perlindungan Anak Indonesia Untuk Mewujudkan Perlindungan Anak, Jurnal Respublica Volume 17, Nomor 2, 2018.

Laurensius Arliman S, Menjerat Pelaku Penyuruh Pengrusakan Barang Milik Orang Lain Dengan Mempertimbangkan Asas Fungsi Sosial, Jurnal Gagasan Hukum, Volume 1, Nomor 1, 2019.

Laurensius Arliman S, Ilmu Perundang-Undangan Yang Baik Untuk Negara Indonesia, Deepublish, Yogyakarta, 2019. 
Laurensius Arliman S, Isdal Veri, Gustiwarni, Elfitrayenti, Ade Sakurawati, Yasri, Pengaruh Karakteristik Individu, Perlindungan Hak Perempuan Terhadap Kualitas Pelayanan Komnas Perempuan Dengan Kompetensi Sumber Daya Manusia Sebagai Variabel Mediasi, Jurnal Menara Ekonomi: Penelitian dan Kajian Ilmiah Bidang Ekonomi, Volume 6, Nomor 2, 2020.

Laurensius Arliman S, Pendidikan Kewarganegaraan, Deepublish, Yogyakarta, 2020.

Laurensius Arliman S, Makna Keuangan Negara Dalam Pasal Pasal 23 E Undang-Undang Dasar 1945, Jurnal Lex Librum, Volume 6, Nomor 2 Juni 2020, http://dx.doi.org/10.46839/lljih.v6i2.151.

Laurensius Arliman S, Kedudukan Lembaga Negara Independen Di Indonesia Untuk Mencapai Tujuan Negara Hukum, Kertha Semaya Journal Ilmu Hukum, Volume 8, Nomor 7, 2020.

Laurensius Arliman S, Pelaksanaan Assesment Oleh Polres Kepulauan Mentawai Sebagai Bentuk Pelaksanaan Rehabilitasi Bagi Pecandu Dan Korban Penyalahgunaan Narkotika, Jurnal Muhakkamah, Volume 5, Nomor 1, 2020.

Laurensius Arliman S, Aswandi Aswandi, Firgi Nurdiansyah, Laxmy Defilah, Nova Sari Yudistia, Ni Putu Eka, Viona Putri, Zakia Zakia, Ernita Arief, Prinsip, Mekanisme Dan Bentuk Pelayanan Informasi Kepada Publik Oleh Direktorat Jenderal Pajak, Volume 17, No Nomor, 2020.

Larensius Arliman S, Koordinasi PT. Pegadaian (Persero) Dengan Direktorat Reserse Narkoba Polda Sumbar Dalam Penimbangan Barang Bukti Penyalahgunaan Narkotika, UIR Law Review, Volume 4, Nomor 2, 2020, https://doi.org/10.25299/uirlrev.2020.vol4(1).3779.

Laurensius Arliman S, Tantangan Pendidikan Kewarganegaraan Pada Revolusi 4.0, Ensiklopedia Sosial Review, Volume 2, Nomor 3, 2020.

Muhammad Afif dan Laurensius Arliman S, Protection Of Children's Rights Of The Islamic And Constitutional Law Perspective Of The Republic Of Indonesia, Proceeding: Internasional Conference On Humanity, Law And Sharia (Ichlash), Volume 1, Nomor 2, 2020.

Otong Rosadi danLaurensius Arliman S, Urgensi Pengaturan Badan Pembinaan Idelogi Pancasila Berdasarkan Undang-Undang Sebagai State Auxiliary Bodies yang Merawat Pancasila dalam Perspektif Hak Asasi Manusia, Prosiding Konferensi Nasional Hak Asasi Manusia, Kebudayaan dan Tujuan Pembangunan Berkelanjutan Indonesia pada Masa Pandemi Covid19: Tantangan untuk Keilmuan Hukum dan Sosial Volume 1, Universitas Pancasila, Jakarta, 2020 . 
